\title{
Tailings Storage Facilities — Decommissioning Planning is Vital for Successful Closure
}

\author{
H.W.B. Lacy Outback Ecology Services, Australia \\ K.L. Barnes Outback Ecology Services, Australia
}

\section{INTRODUCTION}

A major driver for improved planning in closure of Tailing Storage Facilities (TSFs) is that as result of centuries of mining, countless thousands of these particular legacies exist around the world. Rather than increase the number of these legacies and to arrest this problem, implementation of robust decommissioning programmes is required, and in the case of reprocessing or re-mining - the placement of the reworked materials in a safe, stable state is warranted.

\section{WHY PLAN AND THE CONSEQUENCES OF POOR PLANNING}

Studies conducted by Envec (2005) found that "the dominant hazards posed" in relation to mine legacies, are from tailings impoundments. Pollution is mobilised from these impoundments through a number of mechanisms such as from solid airborne transport (tailings dust can contain heavy metals and toxic compounds), mass movements of tails in liquid or semi liquid form, and waterborne as suspended solids and dissolved materials.

Envec (2005) found that in South Eastern Europe fluvial transport of tails can result in large volumes of materials that cause transboundary impacts, with catastrophic damage to downstream land, property and ecosystems. Eco-toxilogical impacts can be catastrophic and can extend far beyond the zone physically damaged, and physical, biochemical and eco-toxicological effects can be very long term. Australasian cases such as Ok-Tedi and the Fly River, the Mt Lyall mine and the Derwent River Estuary, Rum Jungle and the Finniss River - confirm this statement by Envec. Arid regions are no exception to this effect. At Cue in inland West Australia, it was generally thought recreational motor vehicles destabilised the Big Bell tails after the mine's closure in the 1950 's, which then dispersed via fluvial transport with considerable devastation over sixteen kilometres of creek system and into a major salt lake ecosystem (Lacy, 1998).

There is a strong business case for planned vs unplanned closure. Dowd (2005) suggested a managed closure can be one-fifth the cost of closure that is unplanned, for example failure to make cover materials available for waste rock dumps and tailings storage facilities at Newmont Australia, Woodcutters Operation during the operation lead to closure costs of $\mathrm{Au} \$ 40$ million compared to an estimated $\mathrm{Au} \$ 10$ million if progressive reclamation had been integrated into mine planning.

Unplanned closures are not cost effective and often result in sub-standard rehabilitation outcomes, as these works are remedial rather than integrated with mine planning. Sub-standard, unmanaged closures continue to damage the mining industry's reputation. The decommissioned mine is what the industry leave behind as a legacy for future generations. If decommissioning and closure is not undertaken in a planned and effective manner, the mine may remain hazardous and a potential source of pollution for many years to come. On the other hand, a properly decommissioned project, a site that remains safe and stable, is less likely to attract negative comment and to become a social legacy (Lacy in Adams, 2005).

\section{$3 \quad$ IMPORTANCE OF CLOSURE PLANNING DURING DESIGN PHASE}

Tailings closure planning should never be 'an end of mine life process' and should be initiated pre-mining and continue throughout mine life. This is discussed in the Strategic Framework for Tailings Management (MCMPR and MC, 2003) whereby it is stated "Ensure tailings closure planning is an integral component of 
project development, design and operation". The TSF closure plan may evolve over mine life with changes in site conditions, knowledge on tailings properties and best practice.

The Strategic Framework (2003) suggests that the industry can be guided in making decisions about appropriate processes in management of mine wastes (hence tailings), by using hierarchical thinking in order of preference. These are:

- Avoid the generation of waste in the first place (i.e. in situ leaching to acquire the target mineral).

- Reuse - some wastes may be useful for other processes (i.e. utilize smelter gas for acid production).

- Recycle - the raw materials contained may be reusable for further production (i.e. sand - smelting material, and brick production).

- Recovery wastes may be useful for substitution (i.e. as for cemented tails backfill to replace mined backfill).

- Treatment - to make wastes innocuous by further treatment or processing (i.e. removal of pyrite).

- Containment - secure storage of wastes in facilities that are isolated (reasonably) from the environment (i.e. Integrated Waste Landforms).

- Disposal - discharge of waste to the environment under controlled conditions and in a manner which does not harm the beneficial uses is the final alternative.

(Note: suggestions in brackets by authors).

The most important principle when developing a TSF at the design stage is to motivate project planners and tailings consultants to design and engineer out issues associated with long-term liability, and with the "end in mind", that is, of the known reserves. Company planners that have sustained this approach have considerably improved recent tailings construction in Australia. It is also apparent that the leading consultants are encouraging clients to accept designs that particularly avoid the use of tailings in upstream lifts, particularly when run of mine waste is available, and alternatively designing armouring for those TSFs whose walls are made of tailings with under ground development waste post construction (Lacy in Adams, 2005).

In terms of identifying future closure requirements and to plan possible management options of tailings it is important to gain an understanding of the material. Geochemical assessment of drill samples pre-mining during metallurgical testwork, should provide an early indication of the geochemistry of the future tailings, and identify potential decommissioning issues, well before closure. Identification of these issues early in the mine life can guide closure planning toward a particular design and end point. For example, early identification of problematic tailings (which may include tailings which are concentrated in sulphides, heavy metals, and/or salts), may lead the planner to consider an alternative disposal option that may have otherwise not been considered.

Similarly calculations on the quantity of cover material required to cover the TSF can be determined premining to ensure enough material has been stockpiled for the decommissioning phase. These calculations may need to be revised, and quantities potentially increased, if tailings are found to be problematic i.e. potentially acid forming (PAF). The water holding capacity (WHC) of potential cover materials can also be determined pre-mining to ensure enough material has been set aside, although these calculations are often undertaken at the decommissioning phase. Ideally, the planner should conservatively estimate the amount of cover material required, to ensure enough material has been stockpiled for closure works.

Assessment of construction materials pre-mining should determine if materials are geotechnically and environmentally suitable for closure requirements. Materials that are geotechnically stable and have favourable physical and edaphic attributes to support plant growth, have adequate rock fragment and be nondispersive (low in sodium when compared with other cations), and avoidance of the use of tailings for construction of upstream lifts, particularly when run of mine waste is available would be optimal.

TSF wall design should ultimately consider gentle sloping batters or concave slope arrangements overlayed by rocky mulch, vegetated with native, hardy endemic species. Plant roots help bind soil particles together and when combined with a rocky surface soil, can be relatively resistant to erosive effects that cause gully 
development and overall instability. Similarly, appropriate constructed natural slope designs will reduce speed of water flow and dissipate energy more effectively down slope.

Just as important as undertaking adequate investigative work pre-mining, investigative work toward the end of mine life is critical to the success of closure. The geochemical properties of the ore milled at end of mine life will ultimate become the upper, and one of the most important tailings layers. Geochemical assessment is particularly important if previous deposited tailings were found to be PAF. The geochemistry of the upper layers (surface to 4 metres) of tailings material will have a large bearing on TSF water management (i.e. 'water shed' or 'store and release'), final cover type and depth. With adequate pre-planning and investigative work, a non hostile ore can be pre-determined and milled in the closing phases of the TSF's life and form the upper tailings layer. Conversely inhospitable, problematic and phytotoxic materials may be milled early for containment deeper within the facility and/or placed where it can be mitigated and appropriately managed.

The cost of TSF decommissioning can be estimated at an early stage so financial provisions can be set aside. This is particularly important to ensure there are appropriate funds available to close the TSF in later years when revenues are diminishing.

\section{$4 \quad$ ACTIVE PLANNING AND ACTIONS DURING THE MINE LIFE}

There are a number of factors to be considered when preparing to decommission a TSF. The hostile nature of tailings stored in many facilities requires that decommissioning and subsequent rehabilitation is carefully planned and executed. Environmental or climatic conditions must be considered and potential problems likely to affect the long-term integrity of rehabilitation works taken into account (Lacy and Ward, 1998). The factors that influence the rehabilitation of a TSF are:

- Ore type and its geochemistry.

- Process used for ore extraction.

- Process water quality.

- Type of disposal technique.

- Environment where the TSF is situated.

- Compliance requirements.

- The final land use.

- The environmental aspirations of the company (Lacy, 1998).

As with all reclamation processes a staged program is required to capture all decommissioning issues, and a path similar to that developed and used by the authors is suggested in Figure 1.

\section{REGULATIONS, STAKEHOLDERS AND CLOSURE}

Each site has specific commitments and conditions relating to TSF operation and closure, and each county has its own regulatory guidelines, legal information and related literature on TSF closure. These should be reviewed before initiating any closure design.

The environmental operators and closure personnel need to have a clear understanding of their regulatory commitments and conditions related to the TSF. It is not uncommon for a mine site to reach end of mine life and discover regulatory commitments and conditions related to closure conflict with their mine closure plan. In many situations this can easily be avoided by reviewing statutory conditions and commitments that are binding documents and extracting information relevant to closure of the TSF and placing in a separate document that is easily accessed. However this is not to say commitments made ten years previously cannot be superseded as they are no longer relevant due to improved closure techniques and best practice. Discussions with relevant government departments can lead to modifications of conditions to suit an improved closure plan from that that was proposed during the initial mine approval period. 
Stakeholder engagement stands out as one of the most fundamental principles for effective mine decommissioning. Stakeholders include individuals, government agencies, community groups and/or others that are affected by, or have an interest in the mine closure (Lacy in Adams, 2005).

Mining is generally a transient activity, which is often responsible for substantial changes in both the community and the environment in which it operates. Stakeholders' interests often precede the mining operation and remain long after mining ceases. These interests often relate to alternative on-going land uses which can include retention of infrastructure for public use and the maintenance of sustainable non-miningbased communities (WMI, 1994).

Many factors play a large part in reclamation planning: and these include company environmental policy, society's expectations of industry, an understanding of the reclamation requirements and policies of the principal regulatory authorities, and the varied and diverse needs of other stakeholders. Although all these anthropocentric factors drive reclamation planning, ultimately it is the final land use that has to be the prime consideration for reclamation. In some cases this may have values that are not purely confined to immediate human land use needs, but are those of the broader ecosystem in which the tailings remain stored (Lacy, 2005). Identify key stakeholders and involve them throughout the TSF life, and if possible develop a closure plan that is transparent understood and most likely to win their endorsement.

\section{DECOMMISSIONING - EASY OR DIFFICULT?}

Tailings Storage Facility closure is a process of closing down a TSF with the broad objective of leaving the facility safe, stable and non-polluting with little need for on-going maintenance. As stated in the Strategic Framework for Tailings Management (MCMPR and MC, 2003) there are a number of objectives that need to be considered when planning the final landform:

- Containing/encapsulating tailings to prevent leaching into ground and surface waters.

- Provide surface drainage and erosion protection to prevent surface water transporting tailings from the storage area.

- Providing a stabilised surface cover to prevent wind erosion.

- Designing the closure to minimise post-closure maintenance.

The authors have a well-established decommissioning approach and believe tailings decommissioning should be a staged approach. This ensures an appropriate and acceptable decommissioning procedure is followed (Figure 1), and makes the process easy rather than difficult. This approach involves a logical sequence of:

1. Stakeholder discussions and site visit and document review.

2. Sampling, investigations and research as required to define tailings and rehabilitation materials and then in association with other specialist sub-consultants (where required) resolve closure issues.

3. Preparation of the Draft Decommissioning Plan for submission to Regulators.

4. Decommissioning of the TSF and preparation of a Final Decommissioning Report.

5. Monitoring and sign-off.

Stages One and Two (Figure 1) provide the foundation information that guide the TSF decommissioning process toward an appropriate closure strategy. A review of literature is critical and should also incorporate a review of the conditions and commitments related to TSF closure and to ensure compliance with regulations.

Collation and summation of all literature relating to the TSF should provide a solid understanding of the TSF, and expose information that is missing, and investigations that are required to gain a level of understanding that is required before and informative and appropriate closure strategies can be finalised.

Each mine site is often unique in terms of climate, geography, environmental setting, hydrology, mineralogy, and ore processing, just to name a few variables. Thus each TSF is often different and to further complicate matters variability can be found within a single structure. Depending on site issues, closures strategies can be vastly different from site to site, and within a facility between Cells, or separate facilities at the same site. 
Issues affecting closure can be split into four primary areas (geotechnical, geochemical, environmental and hydrological), and examples of common issues and possible closure options are provided below (Table 1).

It should be noted the below table provides only a portion of possible issues and closure strategies and a risk assessment should be undertaken to ensure all issues are adequately identified and managed. This is particularly important for human safety with regard to stability of the TSF in the long term, as this generally is one of the primary risks associated with TSF decommissioning. A well presented assessment prioritises the most serious human safety, health and environmental risk to those that are considered only minor. This allows managers to allocate resources and effort to the issues that pose the highest degree of closure risk.

TAILINGS STORAGE FACILITY DECOMMISSIONG FLOWSHEET

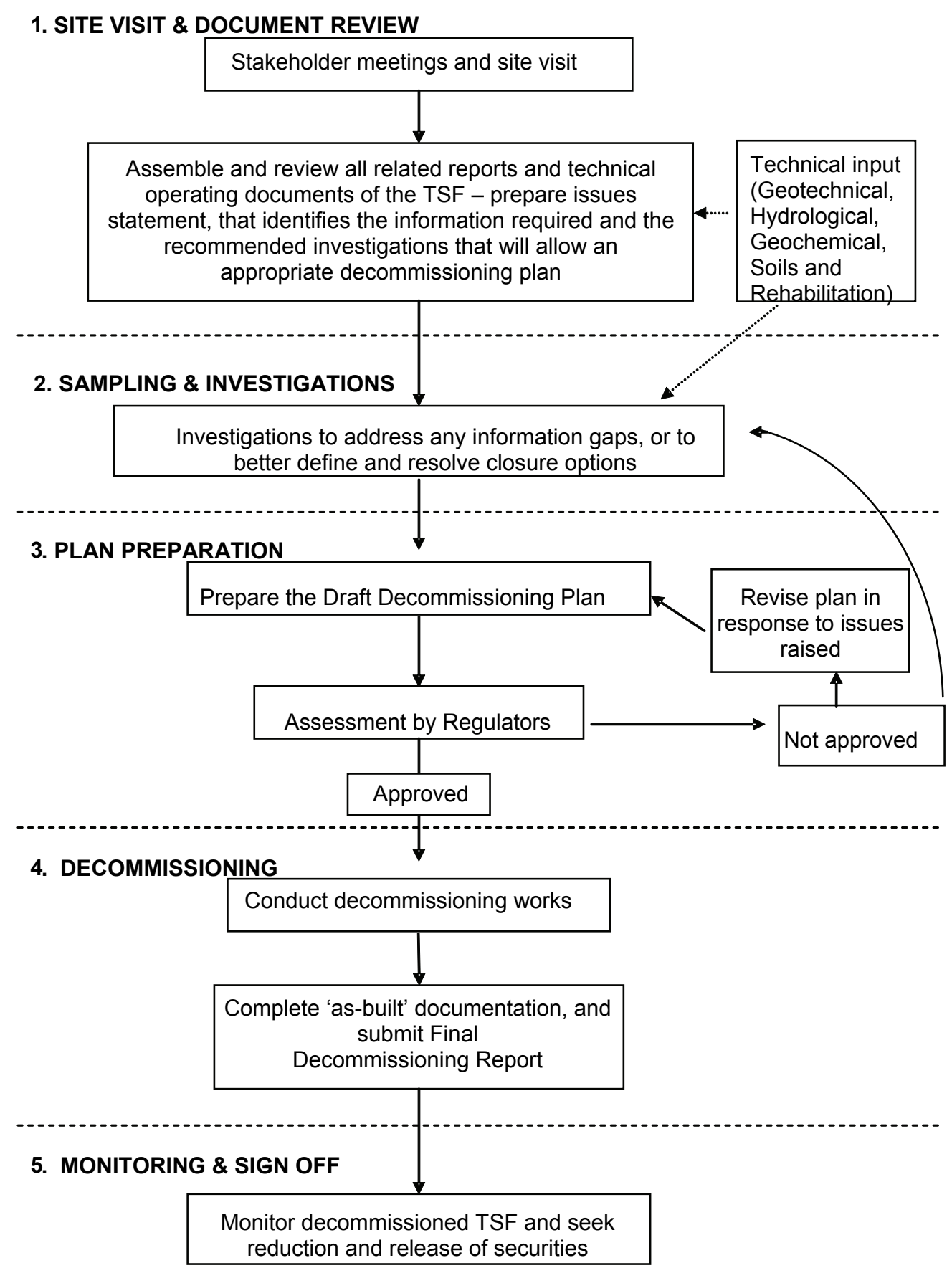

Figure 1 Tailings decommissioning flow sheet (adapted from Lacy and Campbell, 2000) 
Table 1 Tailings Storage Facilities Closure Considerations (Adapted from EA, 2002, Table 5.3, and DITR, 2006, in Draft)

\begin{tabular}{|c|c|}
\hline Issues and Consequences & Options and Techniques \\
\hline 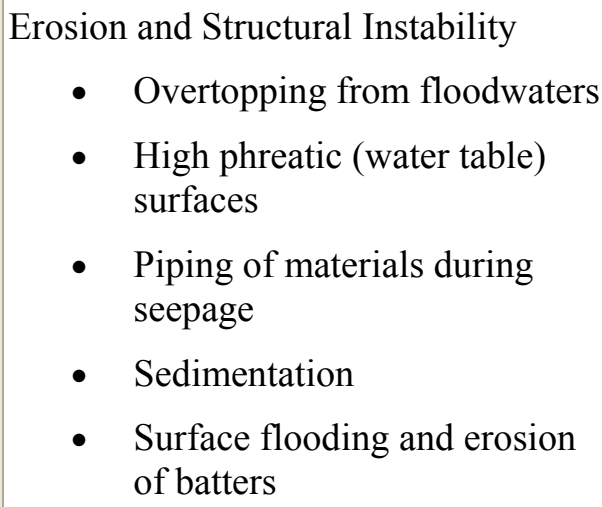 & $\begin{array}{l}\text { - } \text { Geotechnical review/risk assessment on closure } \\
\text { - Integrity from construction phase } \\
\text { - High quality operational management } \\
\text { - } \text { Rock armouring } \\
\text { - Buttressing } \\
\text { - Drainage control } \\
\text { - Erosion resistant cover } \\
\text { - Integration of cover into surrounding environment }\end{array}$ \\
\hline $\begin{array}{l}\text { Acid Rock Drainage } \\
\begin{array}{ll}\text { - } & \text { Internal and external } \\
\text { instability } \\
\text { - } & \text { Water impacts } \\
\text { - } & \text { Acid soil } \\
\text { - } & \text { Toxic to biotic systems } \\
\text { - } & \text { Gas and thermal emissions } \\
\text { - } & \text { Cover deterioration and } \\
& \text { failure }\end{array}\end{array}$ & $\begin{array}{l}\text { - } \text { Geochemical characterisation and selective discharge } \\
\text { - } \text { water and oxygen reactions } \\
\text { - Identification of cover material source and availability } \\
\text { - Monitoring of cover performance and integrity } \\
\text { - Capture store - release systems } \\
\text { - Use as waste backfill in open pits or underground } \\
\text { - Neutralisation (eg lime) and treatment (stimulation of } \\
\text { - Sulphide reducing bacteria) } \\
\text { - } \text { Passive leachate management and treatment }\end{array}$ \\
\hline \begin{tabular}{|ll} 
Dust & \\
- & Visual impact \\
- & Offsite pollution effects \\
- & Flora and fauna
\end{tabular} & $\begin{array}{l}\text { - Surface capping to prevent wind erosion (e.g. rough cover, } \\
\text { rock mulching) } \\
\text { - Revegetation } \\
\text { - Wind breaks } \\
\text { - Hydromulch } \\
\text { Wet cover / wetlands }\end{array}$ \\
\hline $\begin{array}{l}\text { Groundwater } \\
\text { - Aquifer contamination } \\
\text { - Limitation of beneficial use } \\
\text { - Recharge impact } \\
\text { - Localised mounding }\end{array}$ & $\begin{array}{l}\text { - } \\
\text { - } \text { Integrate capture store - release systems } \\
\text { - } \quad \text { Utilise evapotranspiration } \\
\text { - } \quad \text { Cap and cover with capillary break } \\
\text { - } \quad \text { Drainage diversions } \\
\text { - Neutralisation and detoxification of tails seepage } \\
\text { - Wetland filtration }\end{array}$ \\
\hline
\end{tabular}


Table 1 (Cont)

\begin{tabular}{|c|c|}
\hline Issues and Consequences & Options and Techniques \\
\hline $\begin{array}{l}\text { Aesthetics } \\
\text { - High visual impact } \\
\text { - Industry reputation } \\
\text { - Negative public reaction }\end{array}$ & $\begin{array}{l}\text { - Revegetated } \\
\text { - Effective landform and cover design } \\
\text { - Stakeholder engagement to inform development of action plans } \\
\text { to address public concerns }\end{array}$ \\
\hline $\begin{array}{l}\text { Public and Fauna Safety } \\
\text { - Injury or death }\end{array}$ & $\begin{array}{l}\text { - Effective landform and cover design } \\
\text { - Restrict access }\end{array}$ \\
\hline $\begin{array}{l}\text { - Long-term viability of } \\
\text { rehabilitation }\end{array}$ & $\begin{array}{l}\text { - Stock and feral animal control } \\
\text { - } \quad \text { Monitoring } \\
\text { - } \quad \text { Weed control as required }\end{array}$ \\
\hline
\end{tabular}

Stage Three of the staged decommissioning approach (as discussed previously) involves submission of the Draft Decommissioning Plan to the regulators for their review and input, and upon approval of the approach, completion of the decommissioning works (Stage 5) and subsequent preparation of a Final Decommissioning Report.

The overall objective of all decommissioning operations is to gain relinquishment and remove liability. This point is achieved when the company achieves the agreed completion criteria for the TSF decommissioning (as agreed with regulators). Upon completion of earth and rehabilitation works, monitoring and maintenance of the TSF (Stage 5 of the decommissioning approach) need to be undertaken to ensure the facility is stable, vegetated, non-polluting and in overall compliance.

\section{IMPROVEMENTS IN DISPOSAL OF TAILINGS AND INTEGRATION OF MINE WASTE STREAMS}

Tailings, produced in the Australian mining industry, are generally contained in engineered, above-ground structures. In more recent times, these structures have commonly been covered with topsoil and weatheredrock materials to isolate the underlying tailings, contribute to overall stability and support revegetation. Various forms of covering materials, and covering strategies, can be used and has been a focus of the authors for some fifteen years (Lacy et al., 2004).

The authors note with interest that tailings disposal and rehabilitation in Australia has changed considerably over the past fifteen years. There has been a general move away from the typical paddock style, multi-celled square shaped Tailings Storage Facility (TSF), constructed by the upstream method using tailings, to TSFs built with, or encapsulated by, waste rock walls. Other major initiatives are the rapidly increased use of mined out areas (pits) for in-pit disposal of tailings, and increased use of the very stable, large footprint Centrally Thickened Discharge facilities, which brings the more recent and advancing thickened tailing and paste disposal technology into practice (Jewell, 2005).

Recently, a review of published information and experience of staff from Coffey Mining, and Outback Ecology into the design, operational requirements and advantages, and closure requirements of the initiative developed and described by J. C. Lane (1998) as a "Tailings Facility Surrounded by a Waste Dump" was conducted by Landform Solutions (2006) on behalf of Oxiana Ltd. Soil \& Rock Engineering Pty Ltd (now a division of Coffey International Limited) were the originators of the concept of the circular TSF within a Waste Dump and were instrumental in the further development of this concept within W.A. The first case 
study - of the Bronzewing Mine, constructed in 1994, was presented at a conference in Perth 1998 (Lane 1998).

SRE initially started with conventional paddock storage facilities adjacent to and partially enclosed by waste dumps at various sites including Mt Pleasant amongst others. From there the concepts of fully encapsulating the TSF within the waste dump grew. With the increasing integration of the TSF design studies within the whole the mine planning process, opportunities for more efficient use of mine waste resources became apparent. By focusing on the mine waste scheduling process it was possible to optimise the selective use and placement of the various mine waste materials for future embankment construction. The natural progression of this co-operative approach ultimately resulted in the development of large circular TSF's constructed at Bronzewing, followed by Chalice, and Mount McClure - TSF 4 in the early 1990's (pers.com. J.C. Lane).

More recently the Challenger Mine in South Australia adopted the concept that (Sperring and Lacy, 2001) went on to describe as an "Integrated Waste Landform" (IWL), which combines waste rock and tailings material within one structure.

The experience of Coffey and Outback Ecology in the approval, construction, operation and decommissioning of TSFs is; that incorporating the TSF within an Integrated Waste Landform offers benefits in several areas. An important outcome of these benefits is greater regulator confidence. The "IWL" concept brings inherent benefits in long term stability post closure by storing often erosive tailings material well within a waste landform constructed from large open pit mine waste.

Within the review conducted (Landform Solutions, 2006) further defined an Integrated Waste Landform as a landform that "integrates, in immediate proximity, different waste materials generated by a mining operation within multiple facilities in a single structure".

This broadens the definition and concept so that not just tailings, but conceptually heap leaches, Rom pads, acid forming and intractable waste rock materials, mineralised waste, low grade ore and landfill materials could all be considered as part of components that can make up a IWL. Landform Solutions (2006) described the principal benefits of IWLs (as a container for the TSF) as follows:

- Smaller overall disturbance footprint required.

- Large volume of waste material in the external batters, reduces risk of seepage, and increases geotechnical stability.

- Downstream construction of embankment lifts using mine waste ensures no reliance is placed on the strength of the deposited tailings.

- Greater accessibility and working space at embankment level, for all operations.

- Outer batters created from mine waste, which can be selected to have appropriate soil properties and can be progressively rehabilitated.

- Potential for reductions in performance bonds during operations, as a result of progressive rehabilitation.

- Final costs to cover TSF are reduced, due to proximity of suitable waste materials.

- Ability to expand operations and throughput with lessened geotechnical risk.

In the bigger picture of "whole mine decommissioning" it was determined that IWL's provides early opportunities for the application of the concept of progressive rehabilitation (Outback Ecology, 2006). Benefits (both economic and environmental) in progressively rehabilitating IWL landforms as they are constructed include:

- Reductions in waste movements (where practical suitable material can be placed at final destination rather than stockpiled and relocated).

- Dust and water control enhanced through early surface stability of waste materials.

- Enhanced aesthetics and amenity. 
- Environmental liabilities being reduced throughout the life of the project while cash flow is optimal, leaving a reduced amount of closure works required at the end of mine life.

- Reduction in magnitude of closure liability to the state in the event of unforeseen closure of operations.

The authors are of the opinion that IWL's, in general terms, meet to a high degree basic environmental objectives of rehabilitation in accordance with the following criteria related to tailings disposal:

- Disposal of tailings should be non-polluting, both during operation and after de-commissioning.

- The tailings disposal structure should remain stable in the long term with regard to engineering aspects and erosion, and be maintenance free.

- The final landform produced should be compatible with the surrounding landscape (Clarke, 1987).

Notwithstanding some of the considerable improvements the authors see in the future with the application of improved tailings disposal techniques as previously described, tailings decommissioning is still very much a teamwork exercise. Decommissioning is most effective if approached in a systematic way (with no short cuts), and requires a specific understanding of the physical, biogeochemical and geochemical nature of the specific tailings, the facility in which the tailings are stored, and a team of highly experienced people of the appropriate key scientific disciplines to effect a sustained and effective planned closure.

\section{REFERENCES}

Adams, M. (2005) Developments in Minerals Processing Vol. 15. M. Adams (ed), Elsevier BV. Amsterdam, Netherlands.

Clarke, J. (1987) Tailings dam design for rehabilitation. Presented at 1987 Tailings Disposal and Management Seminar, Murdoch University, Perth, W.A.).

Department of Industry, Tourism and Resources (2006) Mine closure and completion - Draft 12, Australian Government, Canberra.

Dowd, P. (2005) The business case for prevention of acid drainage. The International Network for Acid Prevention (INAP) Conference. Fremantle Perth W.A. Keynote speech August 23, 2005.

Envec, Environment Security Initiative (2005) Mining for Closure. Policies and Guidelines for Sustainable Mining Practice and Closure of Mines. South East Europe. UNEP, UNDP, OSCE, NATO.

Environment Australia (2002) Mine decommissioning. Best Practice Environmental Management in Mining. Environment Australia, Canberra. July 2002.

Jewell, R. (2005) Introduction. Sec 1. Paste and Thickened Tailings - A Guide, Second Edition. R.J. Jewell and A.B. Fourie (eds). University of Western Australia Press, Crawley, WA.

Lacy, H. (2005) Closure and Rehabilitation of Tailings Storage Facilities. Developments in Minerals Processing, Vol. 15, M. Adams (ed), Elsevier BV. Amsterdam, Netherlands. Sect 1.4.2.

Lacy H. (1998) Industry practice and research: Vegetation establishment and growth on tailings in arid and semi arid areas of Western Australia. Future Directions in Tailings Management ACMER Workshop Proceedings. 1998. ACMER Kenmore QLD.

Lacy, H. (2002) Reclamation/rehabilitation and closure of tailing storage facilities. Paste and Thickened Tailings - A Guide, R.J. Jewell, A.B. Fourie, E.R. Lord (eds). University of Western Australia Press, Crawley, WA., pp. 135140 .

Lacy, H. (2005) Reclamation/rehabilitation and closure of tailing storage facilities. Paste and Thickened Tailings - A Guide, Second Edition. R.J. Jewell and A.B. Fourie (eds). University of Western Australia Press, Crawley, WA. Sect 11.8 .

Lacy, H. and Campbell, G. (2000) Decommissioning Tailings-Storage Facilities: The challenges and how they are being met during closure of a Nickel-Sulphide Mine in Western Australia, Minerals Council of Australia, 4th International and 25th National Environmental Workshop (2000). Conference Proceedings Perth. W.A. 
Lacy, H. and Ward, J. (1998) Rehabilitation in relation to decommissioning of tailings storage facilities in Western Australia: challenges and solutions. Australian Centre for Geomechanics Workshop, Perth, Western Australia, 1998. University of Western Australia, Crawley, WA.

Lacy, H., Barnes, K., Campbell, G. and Payne, C. (2004) Covers and the closure of tailing storage facilities; making the most of the information and the available materials to close tailings storage facilities. Goldfields Environmental Management Group Workshop, Kalgoorlie, Western Australia, 2004. Goldfields Environmental Management Group, Boulder, WA.

Landform Solutions Pty Ltd (2006) Waste Landform Planning for Prominent Hill, Internal Report for Oxiana Ltd. Unit 1 Troy Terrace Jolimont, Perth. W.A.

Lane, J.C. (1998) Innovative approaches to tailings disposal. Future Directions in Tailings Management ACMER Workshop Proceedings. Perth, W.A. 1998. ACMER PO Box 883, Kenmore QLD.

Ministerial Council on Mineral and Petroleum Resources (MCMPR) and Minerals Council of Australia (MC) (2003) Strategic Framework for Tailings Management. National Capital Printing, Canberra.

Outback Ecology (2006) Conceptual Mine Closure and Rehabilitation Plan. Prominent Hill Copper Gold Project. MARP Preparation For Oxiana Ltd. March 2006.

Sperring, P. and Lacy, H. (2001) Mining Proposal for Challenger Mining Project (MARP). Submitted to PIRSA S. Aust April 2001, by Dominion Mining Ltd. 15 Outram St., Perth. W. Aust.

WMI (Whitehorse Mining Initiative) (1994) Environment Issues Group, Final Report, October 1994 (as referenced in ANZMEC/MCA, 2000). 